\title{
The Presumption of Judicial Vindictiveness in Multi-Count Resentencing
}

\author{
Jonathan D. Youngwood $\dagger$
}

In an effort to safeguard the right to a criminal appeal, the Supreme Court in North Carolina v Pearce ${ }^{1}$ crafted a "prophylactic rule"2 which forbids a judge from increasing a defendant's sentence as punishment for challenging a conviction. In applying this doctrine, the Courts of Appeals agree that when a defendant wins an appeal but loses a second trial, the judge may not increase the sentence without justifying the harsher punishment with an objective rationale. The circuits often differ, however, on the application of Pearce to resentencing in cases involving multi-count convictions. ${ }^{3}$ In such cases, the first trial results in a guilty verdict on more than one count while the second trial ends in acquittal on some, but not all, of the counts that made up the original conviction.

The dispute among the circuits centers on whether the postappeal sentence and the pre-appeal sentence should be compared in the aggregate or on a count-by-count basis. At issue is a conflict between the judiciary's need for discretion in crafting punishments and Pearce's stated goal of eliminating vindictiveness from the sentencing process.

Section I of this Comment examines the development of the Pearce rule as it was created by the Court. The Section also describes the variety of situations in which the Pearce multi-count issue arises and considers the implications posed by the Federal Sentencing Guidelines. Section II examines the Supreme Court's reformulation of the original Pearce doctrine over the past two decades. Section III outlines the approaches to the multi-count issue currently used by the circuits and argues that no court has ade-

† B.A. 1990, Brown University; M.A. 1992, The University of Chicago; J.D. Candidate 1994, The University of Chicago.

395 US 711, 725-26 (1969).

2 Colten v Kentucky, 407 US 104, 118 (1972); Chaffin v Stynchcombe, 412 US 17, 37 (1973) (Stewart dissenting).

3 Compare, for example, United States v Pimienta-Redondo, 874 F2d 9, 12-16 (1st Cir 1989) (en banc) with United States $v$ Monaco, 702 F2d 860, 883-85 (11th Cir 1983). 
quately incorporated the evolution of Pearce into its analysis. Section IV applies the evolved Pearce presumption to the multi-count situation. The Section does not endorse any of the tests currently used by the courts, but constructs a new rule designed to determine when the Pearce presumption applies.

\section{The Original Pearce Presumption of Vindictiveness}

Clifton A. Pearce was serving twelve to fifteen years for assault with intent to commit rape when the Supreme Court of North Carolina granted him a new trial on the ground that the trial judge had unconstitutionally exposed the jury to an invalid confession. ${ }^{4}$ Following a second conviction, the trial judge sentenced Pearce to an eight-year prison term, which, when combined with the time he had already served, amounted to a longer total sentence than the punishment originally imposed..$^{5}$ After the reconviction and the new sentence were affirmed on appeal, ${ }^{6}$ Pearce sought habeas corpus review. The Supreme Court's majority opinion, written by Justice Stewart, rejected claims that either the Double Jeopardy ${ }^{8}$ or Equal Protection ${ }^{9}$ Clause offered a defendant blanket protection against an increased sentence following a suc-

4 State v Pearce, 266 NC 234, 145 SE2d 918, 921 (1966).

- Pearce, 395 US at 713.

- State v Pearce, 268 NC 707, 151 SE2d 571, 572 (1966).

- Pearce, 395 US at 713-14. In Simpson v Rice, Pearce's companion case, Rice had been sentenced to a series of prison terms totaling 10 years after pleading guilty to four charges of second-degree burglary. The court eventually set aside these pleas on the grounds that the trial court had denied Rice his constitutional right to free counsel. The state of North Carolina re-tried and convicted him of three of the offenses. His new set of sentences totaled 25 years. He too sought habeas corpus review. Pearce, 395 US at 714. Alabama $v$ Smith distinguished Simpson v Rice from Pearce and overruled it. See text accompanying note 47.

${ }^{8} 395$ US at 717-21. While this Comment focuses on the application of Pearce and the Due Process Clause to the multi-count fact patterns, other writers have suggested that the Double Jeopardy Clause might also offer protection to the defendant facing resentencing. See Note, Resentencing on Surviving Valid Counts After A Successful Appeal: A Double Jeopardy And Due Process Analysis, 69 Cornell L Rev 342 (1984); Comment, Re-sentencing Defendants and the Protection Against Multiple Punishment, 133 U Pa L Rev 1409 (1985). These arguments are necessarily limited to two situations that differ somewhat from the standard Pearce case: first, where the resentencing takes place following the dismissal of some but not all of the original counts, and second, where the defendant appeals his sentence but does not appeal the underlying conviction. The vast majority of the courts that have examined the multi-count issue in light of the Double Jeopardy Clause have failed to find that the clause offers protection to the multi-count defendant under any circumstance. See, for example, United States v Moore, 710 F2d 270, 271 (6th Cir 1983); United States $v$ Covelli, 738 F2d 847, 862 (7th Cir 1984).

- According to this argument (which the Court rejected), the Equal Protection Clause would bar any increase because only those defendants who seek second trials run the risk of increased punishment. Pearce, 395 US at 722-23. 
cessful appeal. Rather, the holding rested entirely on the Due Process Clause of the Fourteenth Amendment:

Due process of law [] requires that vindictiveness against a defendant for having successfully attacked his first conviction must play no part in the sentence he receives after a new trial. ${ }^{10}$

The Court presented two arguments in support of its holding. First, penalizing those who exercise their right to appeal "would be patently unconstitutional."11 To put a price on the right to appeal, would "place a defendant in the dilemma of making an unfree choice."12 Second, punishing those who do appeal would deter others from exercising their rights in the future. ${ }^{13}$ Due process requires that a defendant be free "of apprehension of [ ] a retaliatory motivation on the part of the sentencing judge."14

Although it failed to impose a total bar to increased sentences, the original Pearce rule was broad and far-reaching; any increase in punishment following an appeal carried a presumption that the increase was the result of vindictiveness. ${ }^{15}$ Pearce created a twopart test to determine whether an increased sentence following a second trial should be allowed to stand. First, determine whether the court has increased the sentence following appeal. Second, determine if the sentencing authority justified the increase. Information used to justify the greater punishment must consist of "identifiable conduct . . . occurring after the time of the original sentencing proceeding" and must have been "made part of the record."16 The original Pearce rule thus protected the defendant who

${ }^{10}$ Id at 725. The Fourteenth Amendment reads in pertinent part: "No State shall make or enforce any law which shall abridge the privileges or immunities of citizens of the United States; nor shall any State deprive any person of life, liberty, or property, without due process of law ...." US Const, Amend XIV, § 1 .

11395 US at 724, quoting United States $v$ Jackson, 390 US 570, 581 (1968). While the "Court has never held that the States are required to establish avenues of appellate review [ ] it is [] fundamental that, once established, these avenues must be kept free of unreasoned distinctions that can only impede open and equal access to the courts." Rinaldi $v$ Yeager, 384 US 305, 310 (1966). See also Griffin v Illinois, 351 US 12, 18 (1956).

${ }_{12} 395$ US at 724, quoting Worcester $v$ Commissioner of Internal Revenue, 370 F2d 713, 718 (1st Cir 1966).

13395 US at 725.

14 Id.

${ }^{15}$ Id at 726. Pearce made no significant effort to actually define vindictiveness. Indeed, a WESTLAW search revealed that prior to Pearce, the Supreme Court had used the term "vindictiveness" only seven times-never specifically defining it. See text accompanying notes 118-20.

16 395 US at 725. 
had been convicted in a retrial following a successful appeal from the mere possibility of vindictiveness. It did not require that the defendant demonstrate proof of actual vindictiveness.

Lower courts have not limited Pearce's application to cases involving resentencing following appeal and a second trial. ${ }^{17}$ Frequently multi-count Pearce cases involve the resentencing of a defendant following appellate dismissal of some, but not all, of the convicted counts. ${ }^{18}$ And while most Pearce multi-count cases involve appeals attacking the validity of a conviction, some cases involve appeals attacking the severity of the sentence imposed by the trial judge. ${ }^{19}$

Despite the many situations in which the presumption of judicial vindictiveness has been applied, no court has thoroughly analyzed the impact of the Federal Sentencing Guidelines ${ }^{20}$ on the significance of Pearce in federal cases. ${ }^{21}$ Nevertheless, the question has special significance for the defendant involved in a federal multi-count case. Prior to the implementation of the Guidelines, judges had wide discretion in their selection of punishments. ${ }^{22}$ Under the Guidelines, an offender's maximum sentence generally may not exceed the minimum possible sentence by more than twenty-five percent. ${ }^{23}$ Even without Pearce, such a narrow range would limit a judge's ability to repackage any aggregate sentence if a substantial portion of an original multi-count conviction were dismissed as a result of an appeal.

${ }^{17}$ The circuits have failed to give this expansion significant weight. See, for example, United States $v$ Vontsteen, 950 F2d 1086, 1092 (5th Cir 1992) (en banc), cert denied 112 S Ct 3039 (1992), citing cases in which other circuits have offered their opinion on the Pearce multi-count issue. A number of the courts included in this list, for example, United States $v$ Hagler, 709 F2d 578 (9th Cir 1983), and Pimienta-Redondo, 874 F2d at 11, do not fit into the traditional Pearce fact pattern.

${ }^{28}$ See, for example, United States v Colunga, 812 F2d 196, 197-98 (5th Cir 1987). See also Hagler, 709 F2d at 579; Vontsteen, 950 F2d at 1088; United States v Markus, 603 F2d 409, 410-12 (2d Cir 1979).

19 See, for example, United States v Jefferson, 760 F2d 821, 825 (7th Cir 1985), vacated and remanded on other grounds by Jefferson $v$ United States, 474 US 806 (1985) ("We see no reason to distinguish [on the basis of Pearce] the case of resentencing after retrial from the case of resentencing after vacation of an illegal sentence.").

${ }^{20}$ Sentencing Reform Act of 1984, Pub L No 98-473, 98 Stat 1837, 1987 (1984), codified at 18 USC $\S \S 3551$ et seq (1988).

${ }^{21}$ See United States v Perez, 904 F2d 142, 150 (2d Cir 199C), for an example of a court that has purposely delayed discussion of the issue. United States $v$ Dominguez, 951 F2d 412, 414-16 (1st Cir 1991), offers a brief discussion of the possible impact of the "relevant conduct" provisions of the Guidelines on Pearce multi-count cases.

${ }^{22}$ See Albert W. Alschuler, Departures and Plea Agreements Under the Sentencing Guidelines, 117 FRD 459, 459-60 (1987).

${ }^{23} 28$ USC \& 994(b)(2) (1988). 
The availability of upward or downward departures, however, dilutes this apparent limitation on discretion. The Guidelines sometimes permit a judge to depart from the table of suggested sentences when she confronts certain aggravating or mitigating circumstances not adequately comprehended by the Guidelines. ${ }^{24} \mathrm{~A}$ judge interested in maintaining the severity of an initial multicount sentence following a successful appeal might attempt to increase the sentence on any individual count through use of an upward departure. In such a situation, Pearce concerns would arise. ${ }^{25}$

\section{The Evolution and Reformulation of Pearce}

Although there have been some alterations to the original Pearce doctrine over the past two decades, it would be an oversimplification to depict this development as nothing more than a uniform retreat from a once-broad rule. ${ }^{26}$ Indeed, the clarification of Pearce has taken place largely within opinions supportive of the original Pearce doctrine. Every Supreme Court case concentrating on Pearce has reaffirmed its basic principle: due process forbids a sentencing authority from punishing a defendant for exercising the right to appeal a conviction. ${ }^{27}$ This Section examines the continuing development of the Pearce rule.

\section{A. From Two Steps to Three}

The cases that have followed Pearce have transformed the original Pearce two-step test into a three-step analysis. This transformation has, in turn, led to a debate over the precise requirements and definition of the new standard.

Under the original Pearce two-step test, courts did not question sentences imposed after successful appeals unless they (1) were greater than the original sentence and (2) could not be justi-

24 18 USC $\S 3553(\mathrm{~b})$ (1988). See United States Sentencing Commission, Guidelines Manual §§ 5K2.0, 4A1.3 (Nov 1992).

15 For an additional discussion of the Guidelines' impact on Pearce multi-count cases, see text accompanying notes $135-40$.

${ }^{28}$ Both commentators and courts have characterized the development of Pearce as a general narrowing of the original doctrine. See, for example, Comment, Limits on Enhanced Sentences Following Appeal and Retrial: Has Pearce Been Pierced?, 19 Conn L Rev 973, 982 (1987); Note, State v Violette: Harsher Resentencing Encounters A Bolder Presumption of Vindictiveness, $43 \mathrm{Me} \mathrm{L} \mathrm{Rev} \mathrm{523,} 523$ (1991); United States $v$ Vontsteen, 910 F2d 187, 193 (5th Cir 1990). See also text accompanying notes 94-98.

${ }^{27}$ See, for example, Bordenkircher v Hayes, 434 US 357, 363 (1978) ("To punish a person because he has done what the law plainly allows him to do is a due process violation of the most basic sort..."); Texas v McCullough, 475 US 134, 138 (1986) ("Beyond doubt, vindictiveness of a sentencing judge is the evil the Court sought to prevent..."). 
fied by new objective information. ${ }^{28}$ Over the next two decades the Court added an intermediate step. Judges must now also determine whether the circumstances surrounding the increase create something like a "reasonable chance" of vindictiveness. Whereas the Pearce presumption originally applied whenever there was any possibility of vindictiveness, ${ }^{29}$ today, the Court views the Pearce presumption as a severe rule ${ }^{30}$ that should be invoked only when necessary.

An exact description or definition of this new middle step remains unclear. Between the original Pearce decision and the Court's most recent comment on the vindictiveness issue in Alabama $v$ Smith, ${ }^{31}$ the standard used to narrow the number of situations worthy of the Pearce rule has varied widely. First, the exact formulation of the reasonable chance standard has proven both malleable and elusive; in labeling this standard, the Court has waffled from "de minimis" chance to "realistic likelihood" to "reasonable likelihood." Second, even assuming a general definition can be attached to reasonable chance, courts have had difficulty measuring the relative likelihood of vindictiveness in any given situation.

1. Labeling the middle step.

The introduction of the new middle step came slowly and without announcement. In Colten $v$ Kentucky, ${ }^{32}$ the first vindictiveness case after Pearce, the Court declined to apply the Pearce presumption to a situation in which the second sentence was imposed by a higher level court rather than by the court which imposed the original sentence. The Court justified its position on the ground that " $[t]$ he possibility of vindictiveness, found to exist in

${ }^{28}$ Pearce, 395 US at 726. Many of the post-Pearce Supreme Court cases have focused on the second prong of the original two-step test. They have helped define exactly what type of "identifiable conduct," id, courts may use to justify an increase in a sentence following a second trial. For example, in Wasman v United States, 468 US 559, 570-72 (1984), the Court held that evidence of intervening convictions can justify a sentence increase following a second trial. McCullough, 475 US at 143-44, held that the judge's exposure to more detailed or more accurate information concerning the crime can also justify an increased sentence.

${ }^{29}$ Pearce, 395 US at 726.

so United States v Goodwin, 457 US 368, 373 (1982) (The Pearce presumption "may operate in the absence of any proof of an improper motive and thus may block a legitimate response to criminal conduct.").

31 490 US 794, 799-801 (1989). See also text accompanying notes $46-51$.

s2 407 US 104 (1972). 
Pearce, is not inherent in the Kentucky two-tier system." ${ }^{33}$ While Colten did not articulate the exact scope or definition of the new standard, it did clearly reject the notion that Pearce applied whenever a court increased a sentence following a second trial.

In Chaffin $v$ Stynchcombe, ${ }^{34}$ the Court held that the Pearce presumption did not apply when the second sentence was handed down by a jury whose members were not aware of the first. While the Court did not clearly articulate when the Pearce presumption should apply, the opinion did suggest a floor below which it should not: the chance of vindictiveness must be something more than "de minimis." "ss

Together, Pearce, Colten and Chaffin indicate that a resentencing will not be presumed vindictive if the circumstances suggest only a remote possibility of vindictiveness. At the same time, the cases hint at a definition of vindictiveness centered on personal grudges. In Colten, the second sentence was handed down by a higher level judge who had nothing to do with the first trial. In Chaffin, the jury could not possibly have been vindictive because it was unaware of the first sentence.

Despite the results reached in these early Pearce cases, it was not until Blackledge $v$ Perry ${ }^{36}$ that the Court formally acknowledged the abandonment of the original "whenever" standard. As if there had never been any doubt, the Court proclaimed that only those increases in punishment "that pose a realistic likelihood of 'vindictiveness' "37 offend the Due Process Clause. The Court made no effort to define the meaning of the term "realistic likelihood," but presented the term as simply a formal description of the rule already used in Pearce, Colten and Chaffin.

In United States v Goodwin, ${ }^{38}$ the "realistic likelihood" standard changed to a "reasonable likelihood" standard. Once again,

${ }^{38}$ Id at 116. Under Kentucky's two-tiered system, inferior courts try less serious cases. Convicted defendants then have the "right to a trial de novo in a court of general jurisdiction." Id at 108.

s4 412 US 17 (1973).

ss Id at 26.

s6 417 US 21 (1974). Blackledge, as well as Bordenkircher, 434 US 357, and Goodwin, 457 US 368, actually concern prosecutorial vindictiveness and not judicial vindictiveness. Nevertheless, the Court has treated prosecutorial vindictiveness and judicial vindictiveness as a single issue, developing a uniform presumption for both types of case. See, for example, Bordenkircher, 434 US at 362.

s7 Blackledge, 417 US at 27. See also Bordenkircher, 434 US at 362.

ss 457 US at 373. There is no indication why the Court made this change or even if the new phrase is intended to signify a substantial alteration to the Pearce rule. The briefs filed continued to use the term "realistic likelihood." See, for example, Brief of Petitioner in 
the Court offered little in the way of a specific definition of the term, relying instead upon an illustration of the standard through citing fact patterns and outcomes in previous cases. The text of Goodwin does, however, indicate a growing reluctance to extend the Pearce rule to new situations. Classifying the Pearce doctrine as an "inflexible presumption," the Court cautioned against using it in too wide a variety of circumstances. ${ }^{3 \theta}$

Both the "reasonable likelihood" standard and the reluctance to extend Pearce remained the rule in Wasman v United States. ${ }^{40}$ Once again, the Court described the Pearce presumption as a severe rule and concluded that it had "been chary about extending [it] when the likelihood of vindictiveness is not as pronounced" as in earlier cases. ${ }^{41}$ Furthermore, in an apparent attempt to emphasize the potential impact of the new middle prong of the three-step test, the Court noted that even "[i]f it was not clear from the Court's holding in Pearce, it is clear from [] subsequent cases ... that due process does not in any sense forbid enhanced sentences or charges, but only enhancement motivated by actual vindictiveness toward the defendant for having exercised guaranteed rights." 42

Texas v McCullough, ${ }^{43}$ decided two years after Wasman, did little to help clarify the second prong. Rather than relying on either the "realistic likelihood" or "reasonable likelihood" tests of Blackledge, Goodwin or Wasman, the Court introduced the phrase "realistic motive."44 Yet, the Court offered no analysis of this new phrase and quickly dismissed the possibility of vindictiveness in the $M c C u l l o u g h$ fact pattern as merely "speculative."45

Alabama $v$ Smith $^{46}$ the most recent significant Pearce case, announced the most restrictive step-two test ever offered by the Court. The Court, overruling Pearce's companion case, Simpson v

Goodwin, 39-41 (Dkt No 80-2195, filed Jan 22, 1982), available on LEXIS (GENFED library, BRIEFS file).

39 457 US at 381.

40468 US 559 (1984).

42 Id at 566.

42 Id at 568.

43475 US 134 (1986) (Pearce presumption does not apply when it is the trial judge, as opposed to an appellate court, which grants the defendant a new trial).

44 Id at 139. ("Presuming vindictiveness [in this case] would be tantamount to presuming that a judge will be vindictive towards a defendant merely because he seeks an acquittal.").

\&5 Id.

480 US 794. 
Rice, ${ }^{47}$ held that the presumption of vindictiveness does not arise when a court reverses a guilty plea and then reconvicts the defendant following a trial. While the Court again declined to specifically define the "reasonable likelihood" standard, ${ }^{48}$ it did loosely associate it with the phrase "more likely than not."49 This standard is met, and the Pearce presumption is defeated, where there exist sufficient possible justifications for the greater sentence. ${ }^{50}$ This approach further weakens the Pearce presumption. ${ }^{\text {s1 }}$

\section{Measuring vindictiveness in a given situation.}

Articulating a minimum chance of vindictiveness to serve as a prerequisite to the invocation of the Pearce presumption answers only half of the question posed by the second prong of the threepart test. Courts must also assess the risk of vindictiveness in a given situation. Through its post-Pearce decisions, the Court has identified at least two criteria relevant to the assessment of the chance that vindictiveness played a role in the decision to increase a sentence: (1) the existence of a true opportunity for retaliation, and (2) the presence of a personal stake in the vindication of the original sentence.

47 In Smith, the Court actually had two lines of precedent from which to choose-Simpson itself, and a line of decisions, including Brady $v$ United States, 397 US $742,750-53$ (1970), and Bordenkircher, 434 US at 360-65, establishing that a guilty plea may be grounds for leniency in punishment. The Court followed the Brady/Bordenkircher line and overruled Simpson.

480 US at 799.

40 Id at 401-02. Interestingly, the Court again flirted with, as it had in Goodwin, a standard that was not proposed in any party's briefs. See Brief of Petitioner (Dkt No 88-333, filed Feb 23, 1989); Brief of Respondent (Dkt No 88-333, filed Apr 16, 1989); Reply Brief of Petitioner (Dkt No 88-333, filed Apr 15, 1989); Brief for the United States as Amicus Curiae (Dkt No 88-333, filed Feb 22, 1989), all available on LEXIS (GENFED library, BRIEFS file).

so Id. The Court identified three justifications for the harsher sentence. First, judges at subsequent trials are generally exposed to a greater range of evidence than they were at prior sentencing hearings. Second, the judge at trial spends more time with the accused, and thus knows her better. Third, a major reason for leniency, the guilty plea, is no longer present.

s1 The importance of this new standard is unclear. A WESTLAW search revealed only two cases which had quoted the "more likely than not" language, Johnson $v$ Vose, 927 F2d 10, 12 (1st Cir 1991), and Turner $v$ Tennessee, 940 F2d 1000, 1002 (6th Cir 1991). Neither, however, expressly applied the "more likely than not" standard, instead treating it as synonymous with the "reasonable likelihood" test.

The more typical lower court response has been to cite Smith for the "reasonable likelihood" test. See, for example, Rock v Zimmerman, 959 F2d 1237, 1256 (3d Cir 1992); United States v Mabry, 953 F2d 127, 133 (4th Cir 1992); United States v Miller, 948 F2d 631, 633 (10th Cir 1991); United States v Vontsteen, 910 F2d 187, 193 (5th Cir 1990). 
Since vindictiveness is unlikely if the second sentencer is unaware that the defendant has even appealed, certainly some situations will not warrant the Pearce presumption. Under the rule that emerged in Colten and Chaffin, "knowledge of a prior sentence" serves as " $[t]$ he first prerequisite for the imposition of a retaliatory penalty . . . ." According to the Court, absent this knowledge there can be no opportunity for vindictiveness. In Colten, the second sentencer was a superior court where defendants convicted of a misdemeanor in an inferior court could request a trial de novo. Kentucky law provided no formal means for this second sentencer to learn of the first sentence. ${ }^{\text {ss }}$ Similarly, in Chaffin the second sentencer was a jury which, as far as the record indicates, was not aware of the prior history of the case. ${ }^{54}$

The Court's position on the second of the two criteria-the presence of a personal stake in the vindication of the original sentence-has been far from consistent. In Chaffin, the Court noted that both an institutional and personal stake in the vindication of the original sentence can contribute to the likelihood that vindictiveness has played a role in the resentencing. ${ }^{.5}$ More recently, however, the dual emphasis on institutional and personal stake in the outcome of a resentencing appears to have faded from the Court's opinions, focusing more on self-vindication. For example, the $\mathrm{McCullough}$ Court found no risk of personal vindictiveness even though the sentencing judge had presided over both trials. Two factors led the court to this finding: (1) the jury, not the judge, handed down the first sentence, and (2) the sentencing judge herself ordered the new trial. The court concluded that when the two sentences are handed down by two different sentencers, "a

82 Chaffin, 412 US at 26.

ss Colten, 407 US at 117-18. As the Court indicated, however, the judge was actually aware of the first sentence because the defendant's counsel had mentioned the initial punishment during closing arguments. Id at $118 \mathrm{n} 14$. The Court, however, discounted the specifics of the case before it, preferring to create a general rule for trials de novo. The Court reasoned: "In all likelihood, the trial de novo court is not even informed of the sentence imposed in the inferior court and can hardly be said to have 'enhanced' the sentence." Id at 118.

54 412 US at 26-27. Attorneys for the state in Chaffin admitted that had the trial been surrounded by sufficient publicity so as to have informed the jurors of the prior sentence, the Pearce presumption might have been necessary. The Court declined to decide whether a jury's knowledge of prior sentencing would always invoke the Pearce presumption. Id at 28 n 14.

ss Id at 27 (A jury, "unlike the judge who has been reversed, will have no personal stake in the prior conviction and no motivation to engage in self-vindication. Similarly, the jury is unlikely to be sensitive to the institutional interests that might occasion higher sentences by a judge desirous of discouraging what he regards as meritless appeals."). 
sentence 'increase' cannot truly be said to have taken place." ${ }^{\text {"so }}$ At least one commentator has gone as far as to suggest that these subsequent decisions indicate that Pearce only applies when the second sentencer is the same as the first sentencer. ${ }^{.7}$

\section{B. The Growing Disfavor of the Deterrence Rationale}

While the importance of preventing vindictiveness remains a central feature in even the most recent Pearce cases, ${ }^{58}$ the Court's earlier emphasis on preventing the fear of vindictiveness, and thereby avoiding the deterrence of appeals, has declined. ${ }^{59}$ This change, specifically relevant to the multi-count issue, represents a departure from the initial Pearce decision in which the Court presented these two goals as co-equal rationales for the adoption of the Pearce presumption. ${ }^{60}$ The decline of the deterrence rationale has not, however, followed a straight path.

The Court's opinion in Chaffin represents its most complete argument against relying upon the defendant's fear of vindictiveness as a justification for the Pearce rule. The Chaffin Court noted that "the likelihood of actually receiving a harsher sentence is quite remote at the time a convicted defendant begins to weigh the question whether he will appeal." ${ }^{61}$ Before even the possibility of a harsher sentence can come into play, four unlikely events must take place: (1) the appeal must succeed, (2) resulting in an order for a new trial (3) which the prosecution decides to pursue and (4) which results in a second conviction. ${ }^{62}$ While the Court admitted that "it may not be wholly unrealistic for a convicted defendant to anticipate the occurrence of each of these events," the Court did not accept "that such speculative prospects interfere with the right to make a free choice whether to appeal."6s

\footnotetext{
so 475 US at 140 . Strangely, in justifying this position, the Court looked to Chaffin, apparently ignoring that case's reference to institutional concerns. See also Thigpen $v$ Roberts, 468 US 27, 31 (1984) (two different prosecutors).

${ }^{37}$ See Comment, 19 Conn L Rev at 982 (cited in note 26).

ss See, for example, Smith, 490 US at 798 (sentencing discretion must not be "exercised with the purpose of punishing a successful appeal"); McCullough, 475 US at 138 ("vindictiveness of a sentencing judge is the evil the Court sought to prevent ...").

60 This second justification for the Pearce presumption is not even mentioned in Smith, 490 US 794.

${ }^{\circ 0}$ See text accompanying notes 11-14.

11 412 US at 33. The Court actually begins its discussion of the deterrence justification by noting that the defendant in Chaffin obviously was not "chilled" in his decision to seek an appeal. Id.

82 Id at 33-34.

os Id at $34-35$.
} 
Despite the apparent assuredness of the Chaffin Court's dismissal of the deterrence concern, some recent cases continue to recognize the risk of chilling appeals. The Wasman opinion, for example, recognized that one of the goals of Pearce was to "allay any fear on the part of a defendant that an increased sentence is in fact the product of vindictiveness ...." While the Court has clearly retreated from its initial reliance on the deterrence rationale, it has not. completely rejected it.65

Although the Court's subsequent treatment of Pearce has modified the initial Pearce doctrine, the general bar against vindictiveness in sentencing remains. Examination of the multi-count Pearce issue should be conducted through the new three-step Pearce test and with the understanding that the deterrence issue is no longer a significant concern of the Court-parameters to which the lower courts have failed to adhere.

\section{The Multi-Count Issue in the Lower Courts}

Nine circuits have considered the application of Pearce to a situation involving a defendant originally convicted of more than one crime. ${ }^{6 B} \mathrm{~A}$ substantial majority has adopted an "aggregate package" approach, contending that all a court need do to satisfy Pearce is to set the second sentence equal to or less than the original sentence. The dominant minority view advocates a "modified aggregate package" test under which the second sentence may not exceed the aggregate of the original sentences attached to the counts not dismissed as a result of the appeal. Others suggest either a count-by-count system of comparison or a form of proportional resentencing. This Section outlines these various approaches and the rationales behind them.

4468 US at 564. See also McCullough, 475 US at 143 (acknowledging that concern for the "chilling effect" is a consideration even if it is not a "sufficient reason [on its own] to create a constitutional prohibition against considering relevant information in assessing sentences").

${ }^{\text {Bs }}$ One method of testing the Chaffin argument against the significance of the deterrence rationale would be a quantitative study of Pearce's effect on the appeals rate of criminal convictions. However, as the Chaffin court notes, "in part as a consequence of decisions removing roadblocks and disincentives to appeal," the appeals rate in both the federal and state courts has been rising significantly for years, thereby making a reliable statistical comparison extremely difficult. 412 US at $34 \mathrm{n} 22$.

${ }^{68}$ See cases cited in notes 67 and 71 . 
A. The Prevailing View: The "Aggregate Package" Approach

In considering the multi-count Pearce issue, the "aggregate package" courts focus on the lack of a "net increase in [] punishment." ${ }^{67}$ For these courts, a sentence is the total amount of punishment imposed for the collection of crimes for which the defendant is convicted.

For example, in United States $v$ Bay, ${ }^{68}$ a United States District Court originally convicted defendant Thaeeb Bay of two armed bank robberies and one unarmed bank robbery. The judge sentenced him to twenty years for the first armed robbery, ten for the second and five years probation for the unarmed robbery. All sentences were to run consecutively. Thus, Bay's total original sentence was thirty years imprisonment to be followed by five years probation. Bay appealed his convictions and eventually received a second trial. This time the government's success was limited to a conviction on the third count, the unarmed bank robbery. Rather than reinstate the original five year probation sentence, the judge imposed a twenty-year prison term. Bay appealed, claiming that the increase from five years probation to twenty years prison time on the one count violated Pearce. ${ }^{69}$ The Ninth Circuit rejected this contention, holding that Pearce was not a consideration when the defendant does not receive a " 'net increase' in his sentence following the retrial." "7o

\section{B. Alternatives to the "Aggregate Package" Approach}

Two circuits, the Second and the Eleventh, have endorsed an alternative solution to the multi-count Pearce problem. ${ }^{71}$ Nevertheless, the most vigorous and well-reasoned opposition to the "ag-

or United States $v$ Hagler, 709 F2d 578, 579 (9th Cir 1983). See also United States $v$ Sullivan, 967 F2d 370, 374 (10th Cir 1992), cert denied 113 S Ct 285 (1992), and cert denied, 113 S Ct 1013 (1993) ("We must examine [the defendant's] sentences in the aggregate rather than count by count."); Kelly v Neubert, 898 F2d 15, 16 (3d Cir 1990) ("We hold .. . that a restructuring of a sentence does not trigger the Pearce rule when the aggregate sentence is less than that originally imposed ..."). Three other circuits have also adopted the "aggregate package" approach: United States v Pimienta-Redondo, 874 F2d 9, 15 (1st Cir 1989); United States v Gray, 852 F2d 136, 138-39 (4th Cir 1988); United States v Shue, 825 F2d 1111, 1113-16 (7th Cir 1987).

os 820 F2d 1511, 1512 (9th Cir 1987).

69 Id at 1512-13.

70 Id at 1513. The Court further noted that "[i]n fact, Bay's total sentence was reduced." Id.

71 See United States v Markus, 603 F2d 409, 412-14 (2d Cir 1979); United States $v$ Monaco, 702 F2d 860, 883-85 (11th Cir 1983). United States $v$ Henry, 709 F2d 298, 315 (5th Cir 1983), offers a thoughtful argument, in dictum, against the "aggregate package" ap- 
gregate package" approach comes in the form of dissents to the "aggregate package" court opinions. ${ }^{72}$

1. The "modified aggregate package" approach.

The "modified aggregate package" was the position endorsed by two of the first circuits to consider the issue. ${ }^{73}$ As expressed by the Second Circuit in United States $v$ Markus, when facing a multi-count Pearce resentencing problem, "the proper procedure is first to disregard the sentence originally imposed [on any dropped, dismissed or acquitted counts] and then compare the total remaining sentence ...." with the group of sentences imposed after appeal. ${ }^{74}$

For example, in United States $v$ Monaco ${ }^{75}$ one of the defendants, Eugene O. Hicks, was originally convicted on three counts arising out of the illegal importation of marijuana. The judge at the first trial sentenced Hicks to two years imprisonment followed by two years parole on the first count and one year imprisonment followed by two years parole on each of the second and third counts. Hicks was to serve all sentences consecutively, bringing his total punishment to four years imprisonment followed by six years of parole. He appealed and received a new trial which resulted in convictions on only the first two of the original three counts. At his resentencing, Hicks received four years imprisonment followed by four years parole on each of the two remaining convictions, these new sentences to run concurrently. ${ }^{76}$ Focusing on the four-year prison term, the Eleventh Circuit, citing Markus, ruled that such an enhancement of the sentence attached to the individual count violated the spirit of Pearce and could not be permitted. ${ }^{77}$ Under the "modified aggregate package" approach, therefore, Hicks's second sentence could not exceed three years imprisonment.

proach. However, the Fifth Circuit has not expressly adopted either approach. See Vontsteen, 950 F2d at 1092-98.

${ }^{72}$ See, for example, Bay, 820 F2d at 1515-17 (Canby dissenting); Pimienta-Redondo, 874 F2d at $17-20$ (Coffin and Bownes dissenting); Vontsteen, 910 F2d 187 at 194-98 (Rubin dissenting).

${ }^{73}$ Markus, 603 F2d 409, handed down in 1979, represents the first resolution of the issue by a circuit court. Monaco, 702 F2d 860 , followed four years later-before most of the circuits had expressed an opinion on the issue.

74603 F2d at 413 .

702 F2d 860, 883 (11th Cir 1983).

78 Id.

77 Id at 884-85. 
2. A count-by-count comparison rule.

Under a count-by-count rule, courts would compare the sentence attached to each count of an original conviction to the sentence attached to each count following appeal. ${ }^{78}$ If the second set of sentences were greater than the first set of sentences on any individual count, the Pearce presumption would apply. Essentially, a count-by-count rule would freeze the sentences for each count at the time they were initially announced; only downward adjustments would be permitted.

Despite its inherent simplicity, no court has endorsed the count-by-count rule. Overall, this approach leads to results which are essentially indistinguishable from the "modified aggregate package" approach. Under both systems, a second set of sentences which exceeds the aggregate of the sentences originally attached to the non-dismissed counts will invoke the Pearce presumption. Nevertheless, as discussed below, this pure form of the count-bycount approach serves as an excellent beginning to a new method of analyzing multi-count Pearce cases. ${ }^{79}$

3. The proportional approach.

In his dissent in United States $v$ Bay ${ }^{80}$ Judge Canby proposed a rule under which the original sentence is compared to the sentence following the second trial as a percentage of the maximum sentence allowed both before and after the appeal. Following the first trial, Bay faced a maximum punishment of seventy years on the three counts. The trial judge imposed a total sentence of thirty years, or forty-three percent of the maximum allowed. The maximum allowed following the second sentence was twenty years. Therefore, on Judge Canby's reasoning, any second sentence which exceeded forty-three percent of twenty years (8.57 years) would invoke the Pearce presumption. ${ }^{81}$ Since the actual second sentence was twenty years and the facts failed to justify such an "enhancement," Judge Canby found that the resentencing violated Pearce.

7s See Wood v State, $582 \mathrm{~S} 2 \mathrm{~d}$ 751, 754-55 (Fla App, 1991) (Diamantis concurring).

7 See Section IV.

so $820 \mathrm{~F} 2 \mathrm{~d}$ at 1515-17 (Canby dissenting).

81 Id at 1516-17. Judge Canby suggested restricting the use of his proportional rule to cases involving convictions arising out of distinct criminal transactions. Id at 1515-16. 
C. Analysis of the Arguments Presented by "Aggregate Package" Courts

Courts adopting the "aggregate package" approach have advanced four distinct rationales in support of their position. First, they contend that multi-count sentences are packages that might need to be adjusted after a successful appeal. Second, they dismiss the effect of their rule on the deterrence of appeals. Third, several of these courts argue that the general narrowing of Pearce by the Supreme Court over the past two decades suggests that the Court would accept their solution to the multi-count problem. Finally, several opinions attempt to counter an argument that anti-"aggregate package" opinions never raise: that a defendant has a right to rely upon the apparent permanence of a sentence originally attached to each individual count. Unfortunately, no court has adequately incorporated the development of the Pearce test into its analysis

\section{A sentence is a package.}

The argument used most frequently to support the "aggregate package" position focuses on a judge's need for discretion in sentencing. According to the "aggregate package" courts, when considering punishment for a defendant convicted of a number of crimes, the judge does not attach sentences individually to each count but rather assembles a "package." ${ }^{\text {"2 }}$ Accordingly, "[w] hen the conviction on one or more of the component counts is vacated, common sense dictates that the judge should be free to review the efficacy of what remains in light of the original plan, and to reconstruct the sentencing architecture upon remand ...." their initial sentences would unfairly limit their powers: "After an appellate court unwraps the package and removes one or more charges from its confines, the sentencing judge, herself, is in the best position to assess the effect of the withdrawal and to redefine the package's size and shape ...."

The "aggregate package" courts base their discretion argument in part on the theory that punishment must suit both the criminal and the crime. ${ }^{85}$ Courts in favor of the "aggregate pack-

${ }^{82}$ Pimienta-Redondo, 874 F2d at 14.

ss Id.

${ }^{84}$ Id.

${ }^{85}$ See Williams v New York, 337 US 241, 247 (1949) ("Highly relevant-if not essential-to [the] selection of an appropriate sentence is the possession [by the judge] of the fullest information possible concerning the defendant's life and characteristics."); Bay, 820 
age" theory contend that when determining a sentence, "[a] judge does not calculate a sentence solely on the basis of the nature of the crime involved. The judge must also consider the character of the defendant: his life, health, habits, conduct, and mental and moral propensities." ual charged and the various crimes for which he may or may not be convicted, "[i]t is incorrect to view the total sentence imposed upon such a defendant as resulting from nothing more than a mathematical addition of each crime upon which he was convicted." $" 87$

Those opinions which reject the "aggregate package" approach place a greater emphasis on the statutorily described crime. ${ }^{88} \mathrm{In}$ deed, one dissent termed the concept of "retrofitting" the sentence so as to render the total punishment following appeal substantially the same as the punishment awarded prior to the appeal as "demeaning." bles a sentencing plan, commenting that "the only stable factor in the 'plan' is the bottom line ....".90 Furthermore, allowing a judge to leave the total sentence unchanged after she has dismissed certain counts, without justifying this decision through objective information, might actually discourage judges from seriously reexamining their initial package of punishments.

\section{Deterring appeals.}

"Aggregate package" courts summarily dismiss concerns that their solution to the multi-count problem will result in the unjust deterrence of appeals. These courts contend that so long as there is no danger of an increased sentence, there can be no deterrent effect; after all, they argue, at worst the defendant pursuing the appeal will break even. ${ }^{91}$ By contrast, opinions in favor of alternatives to the "aggregate package" approach argue that to allow a sentence to remain unchanged after the vast majority of counts have been

F2d at 1514 ("The punishment should fit the offender and not merely the crime."). For criticism of the assumptions underlying Williams, see notes 104-113 and accompanying text.

Bs Bay, 820 F2d at 1513 .

87 Id at 1514.

ss In Henry, 709 F2d at 310, the Fifth Circuit presents a definition of the word "sentence" that is significantly at odds with the notion of sentencing as a "package." If this view of sentencing is correct, see Section IV.A., the increase of the sentence attached to any single count would risk violating Pearce.

so Pimienta-Redondo, 874 F2d at 19 (Coffin and Bownes dissenting).

${ }^{\circ 0}$ Id.

-1 See, for example, United States v Busic, 639 F2d 940, 951 n 12 (3d Cir 1981). 
dismissed is sure to appear "chilling to a putative appellant." Whatever the merits of the arguments presented by both groups, the Supreme Court's more recent decisions have downplayed the importance of the deterrence goal altogether..$^{93}$

\section{Development of the Pearce doctrine.}

Courts have also looked to the direction the Supreme Court has taken on the original Pearce presumption over the past two decades. The "aggregate package" courts argue that the original Pearce rule "has not been broadened [and] arguably, it has been narrowed." These courts caution that "[i]t is important that the Pearce principle not be blown out of proportion." cating alternatives to the "aggregate package" approach read these same post-Pearce cases in a different light. While some either ignore the subsequent Supreme Court commentary on Pearce ${ }^{96}$ or simply assert that they "find no such flow in the post-Pearce opinions,"97 others contend that the rule announced in Pearce is actually quite "broad."

The argument implied by this discussion, is, however, somewhat unfocused and it ignores the specifics of the transformation of Pearce from a two-step to a three-step rule. The courts on both sides of the issue appear to assume that if the Court has narrowed the practical effect of the Pearce presumption in a number of situations, then the Court is likely to give the multi-count Pearce issue a similarly anti-defendant reading. But such an oversimplification is hardly conclusive. Even if the Supreme Court has narrowed Pearce in some ways, that does not settle the issue of what to do in multi-count cases, nor does it mean that future Pearce decisions will further restrict the reaches of the doctrine. Furthermore, it is highly questionable whether an appellate judge should guess the future direction of the Supreme Court rather than seek the correct result within the limits of the existing doctrine.

${ }^{92}$ Pimienta-Redondo, 874 F2d at 19 (Coffin and Bownes dissenting).

${ }^{93}$ See Section II.B.

24 Vontsteen, $910 \mathrm{~F} 2 \mathrm{~d}$ at 193.

os Pimienta-Redondo, 874 F2d at 12.

${ }^{83}$ See Markus, 603 F2d at 411-15 (containing no reference to any post-Pearce Supreme Court case).

${ }^{87}$ Vontsteen, $910 \mathrm{~F} 2 \mathrm{~d}$ at 197 (Rubin dissenting).

${ }^{98}$ See, for example, Monaco, 702 F2d at 883. 
4. Reliance on the original sentence.

Several of the "aggregate package" courts have devoted significant effort to arguing that a defendant who has been convicted on multiple counts has no right to expect that her sentence on any individual count will not increase following a successful appeal.99 As the Ninth Circuit notes, "[t]here is simply not the finality to a sentence as there is to an acquittal, and there is no right to know as of a particular time what the sentence will be."100

While the text of the opinions does not always make it clear, this is essentially a double jeopardy argument; ${ }^{101}$ it does not speak to Pearce's interpretation of the Due Process Clause. Notably, even the opponents of the aggregate package approach do not argue that Pearce guarantees that convicted defendants may rely on the finality of their original sentences.

Although courts have been analyzing the multi-count issue for more than a decade, the method of analysis has remained largely unchanged. The circuits have paid insufficient attention to the development of the Pearce doctrine from a two-step to a three-step test. ${ }^{102}$ The final Section of this Comment analyzes the multi-count Pearce issue within the context of the current three-step analysis. Careful adherence to this evolution demands a completely new approach.

\section{The Three-Step Test Applied to the Multi-Count Issue}

This Section begins by applying step one of the three-step Pearce test to the multi-count situation. Agreeing upon a definition of the word "sentence" is a crucial task in these multi-count cases. If sentence means the aggregate of punishment assigned on all of the separate charges at the conclusion of a trial, there is no need to extend the analysis of the multi-count cases to step two of the three-step analysis. But if "sentence" means punishment associated with a single count, then the decision to increase the pun-

See, for example, Busic, 639 F2d at 952 n 13.

${ }^{100}$ Hagler, 709 F2d at 579.

${ }^{101}$ For cases and commentary discussing multi-count resentencing and the Double Jeopardy Clause, see note 8.

102 The first Pearce multi-count issue case was decided in 1979, before more than half of the post-Pearce Supreme Court decisions had come down, see Markus, 603 F2d 409, and the most recent multi-count Pearce case came as recently as June, 1992, see Sullivan, 967 F2d 370. Circuits that have issued recent Pearce multi-count decisions justify their current position by relying on the precedent of older decisions within their circuit without acknowledging the change in the Pearce rule since the original decision. See, for example, Bay, 820 F2d at 1513, citing Hagler, 709 F2d 578. 
ishment attached to each of these counts must be examined under the second step of the test: the likelihood of vindictiveness in multi-count cases. Only those sentences which increase in a way in which there is a "reasonable likelihood" of vindictiveness invoke the Pearce presumption. What emerges is, in essence, a modified version of the count-by-count comparison rule. By separating step one, the question of increase, from step two, the reasonable likelihood of vindictiveness, it is possible that some multi-count cases will invoke the Pearce presumption while others will not. This Section completes its application of the three-step test to the multicount situation with a brief look at the third step and concludes with a discussion of some of the possible benefits of the proposed approach.

A. Step One: When Is a Sentence Increased in a Multi-Count Case?

In multi-count cases, a proper application of step one of the three-step test requires a count-by-count comparison of the preappeal and post-appeal sets of sentences. An opposite reading-the one made by the aggregate package courts-confuses the word "sentence" with the old practice of general sentencing. Under this now disfavored system, a judge pondering a multi-count conviction may hand down a single, comprehensive sentence to cover the entire set of statutory offenses rather than assign a distinct sentence to each violation of the criminal code. ${ }^{103}$ Any effort to lump together the individual sentences that make up a multi-count Pearce conviction is equivalent to treating them as a general sentence whether they were orginally intended that way or not.

In support of their general sentencing argument, the aggregate package courts suggest that multi-count convictions involve the crafting of unitary packages rather than the grouping of separate

${ }^{103}$ See Bensen v United States, 332 F2d 288, 289-90 (5th Cir 1964). The Bensen court vacated and remanded a "general sentence" of 15 years imposed after conviction on three separate counts. Noting that general sentences were universally recognized as unsatisfactory, id at 290 , the court based its holding on the argument that general sentences shrouded the sentencing process in "inscrutable mystery," id at 292 , thereby preventing the accused, reviewing courts, and prison authorities from knowing "what the real sentence is." Id at 291. Because a sentence is passed for the violation of a "specific transgression" rather than "because the defendant is a social outcast [who] needs chastisement generally," the law demands that an "articulate, identifiable sentence [be] imposed" on each count. Id. See also Peoples $v$ United States, 412 F2d 5, 6-7 (8th Cir 1969); United States $v$ Straite, 425 F2d 594, 596 (DC Cir 1970). 
statutory offenses. ${ }^{104}$ It is a view based largely on Williams $v$ New York, ${ }^{105}$ which held in part that the character of a defendant must be considered during the sentencing. Yet the Williams decision was based on assumptions and conditions that no longer hold or exist. ${ }^{108}$ Most significantly, Williams was written when rehabilitation was still seen as a major and realistic goal of the criminal justice system, a contention few would put forth today. ${ }^{107}$ In addition, Williams, was written in an era of indeterminate sentencing. ${ }^{108} \mathrm{By}$ contrast, the trend now is toward a system of determinate sentencing "premised on the notion that judges' discretion should be [] narrowly constrained . . . ."

The view of a sentence as a package has been strongly challenged in the circuits by the common sense approach of the modified aggregate package courts. These courts have, in effect, argued that to allow judges to view separate statutory crimes as interchangeable parts in a package is to demean the sentencing process. ${ }^{110}$ As the Fifth Circuit notes in United States $v$ Henry, a sentence "is the specific consequence of a specific violation of a specific [] statute."111 The Henry Court supports its view with an analysis of federal statutory law. ${ }^{112}$ Furthermore, this use of "sentence" is consistent with the analysis the Supreme Court has used to define the concept of "same offense" in the context of the Double Jeopardy Clause. ${ }^{113}$

204 See text accompanying notes $82-90$.

105337 US 241, 247 (1949).

108 Daniel J. Freed, Federal Sentencing in the Wake of Guidelines: Unacceptable Limits on the Discretion of Sentencers, 101 Yale L J 1681, 1713 (1992).

107 Id.

108 Id.

100 Michael Tonry, Salvaging the Sentencing Guidelines in Seven Easy Steps, 4 Fed Sent Rep 355, 357 (1992).

110 See text accompanying notes 73-77.

$11709 \mathrm{~F} 2 \mathrm{~d}$ at 310 (emphasis in original).

112 Despite evidence that judges value their discretion in sentencing and tend to consider the entire criminal transaction when issuing sentences, see Stephen J. Schulhofer, Due Process of Sentencing, 128 U Pa L Rev 733, 757 (1980) ("criminal sentencing decisions are based heavily upon actual offense behavior as distinguished from the formal offense of conviction"), "[a] sentence in a criminal case is the action of the Court fixing and declaring the legal consequences of predetermined guilt of a criminal offense." Barnes $v$ United States, 223 F2d 891, 892 (5th Cir 1955). An offense is, in turn, defined numerous times throughout the United States Code as any "criminal [act] ... which is in violation of an Act of Congress and is triable in any court established by Act of Congress." For example, 18 USCA § 3156 (a)(2) (1988) (emphasis added). See also 18 USCA \& 3172 (2) (emphasis added) (using nearly identical language).

11s See Blockburger v United States, 284 US 299, 304 (1932) (two statutory offenses may arise from a single act if one offense "requires proof of an additional fact which the other does not . . . ."); Brown v Ohio 432 US 161, 165-66 (1977). While Grady v Corbin, 495 
At every step in the criminal process, sentences attached to individual crimes, even those in a multi-count indictment, are handled separately from one another. Legislatures have assigned every statutory crime its awn individual potential punishment. These punishments may, in turn, be appealed individually on their own merits and they may be upheld or overturned by an appellate court individually. Trying a set of crimes together does not mean that they or the punishments attached to them become inseparable.

The view of sentence argued for in this Section is in partial conflict with the modified real offense system of sentencing adopted in the Federal Sentencing Guidelines. Under this system, judges confronting certain situations may base sentences on all "relevant conduct" associated with the statutory crime for which the defendant has been convicted. ${ }^{114}$ The Sentencing Commission was willing to view certain collections of crimes as being part of a package of criminal behavior. Yet, there is no compelling reason that the view of one sentencing authority should dominate the interpretation of a constitutional provision. In including the "relevant conduct" provisions, the Commission was reacting in large part to the fear that pure charge offense systems placed too much power in the hands of the prosecutor. ${ }^{115}$ Rather than risk the abuse of such power, the Commission decided to place some of this power in the hands of the judge. But Pearce's concern, at least in multicount resentencing cases, is with the potential for judicial, not prosecutorial, abuse. Furthermore, many states that have considered the "relevant conduct" issue have opted for a strict chargebased system. ${ }^{116}$ If a multi-count rule is to be applicable to all jurisdictions, it cannot be based solely on the specifics of federal practice.

Were the original Pearce rule and its two-step analysis still the law, the analysis of the multi-count issue could end here with a

US 508 (1990), narrowed the Blockburger test under certain circumstances, it still left a rule in place which views most separate statutory crimes as distinct legal offenses.

114 Guidelines Manual, § $1 \mathrm{~B} 1.3$ (cited in note 24).

118 Freed, 101 Yale L J at 1713 (cited in note 106). See generally, Kevin R. Reitz, Sentencing Facts: Travesties of Real Offense Sentencing, 45 Stan L Rev 523 (1993); William W. Wilkins and John R. Steer, Relevant Conduct: The Cornerstone of the Federal Sentencing Guidelines, 41 SC L Rev 495 (1990); Marc Miller and Ronald Weich, The Relevant Conduct Controversy, 2 Fed Sent Rep 150 (1989).

${ }^{110}$ Freed, 101 Yale L J 1713 n 168 (cited in note 106). In addition, the "relevant conduct" provision is one of the more criticized aspects of the Guidelines. See, for example, id at 1712-15; Tonry, 4 Fed Sent Rep 355 (cited in note 109); United States $v$ Fine, 946 F2d 650, 651-52 (9th Cir 1991). 
simple determination. Contrary to the rule of the majority of the circuits, an increase of any individual count of a multi-count conviction qualifies as an increase for Pearce purposes. The adoption of the intermediate second step, however, requires further analysis.

B. Step Two: When Does the Increase of a Sentence in a MultiCount Pearce Case Indicate a "Reasonable Likelihood" of Vindictiveness?

Agreeing that for purposes of Pearce judges must compare sentences count-by-count does not necessarily mean that any increase in a sentence attached to an individual count following appeal invokes the Pearce presumption. Under the second step of the three-step Pearce test, only those increases that occur under circumstances that indicate a "reasonable likelihood" that vindictiveness played a role in the enhancement must be justified by objective information on the record. ${ }^{117}$

1. Vindictiveness in the multi-count context.

Despite repeated consideration of the Pearce issue, the Court has not focused on the definition of vindictiveness. ${ }^{118}$ The lower courts have generally classified Pearce vindictiveness as "the imposition of some punishment against defendant in retaliation for defendant's exercise of a legal right." 119 The classic Pearce case, an unjustified increase in the punishment associated with a singlecount conviction following a successful appeal, fits well within this definition.

Many of the circuits have argued that absent this threat of actual increase in sentence, there is no possibility of vindictiveness. ${ }^{120}$ Should this narrow view of vindictiveness prevail, no multicount case, even if it involves increases in individual counts, will invoke the Pearce presumption unless the court has also increased the aggregate sentence.

But in the multi-count context, such an understanding of vindictiveness is too limited. In the classic Pearce case, the judge has violated the defendant's right to due process by, in effect, declaring

117 See Section II.A.

${ }_{118}$ Bordenkircher, 434 US at 363 , a post-Pearce vindictiveness case, comes close to offering a definition in stating that " $[t]$ o punish a person because he has done what the law plainly allows him to do is a due process violation of the most basic sort . . .."

110 United States v Mulherin, 529 F Supp 916, 929 (S D Ga 1981), affd 710 F2d 731 (11th Cir 1983). See also, United States v Blanchette, 17 MJ 512, 514 (AFCMR 1983).

120 See text accompanying notes 91-93. 
"I'll show you there's a price to pay for appealing one of my decisions." Such a statement does not appear significantly different, nor more vindictive, than the judge in the multi-count case who, by adopting the "aggregate package" approach, says "I'll show you there's no profit in appealing one of my decisions." Both actions punish the defendant by negating her wholly legal and proper appellate efforts; they both deprive her of the right to attempt to reduce her punishment.

2. "Reasonable likelihood" in the multi-count context.

Accepting this broader definition of vindictiveness does not make the Pearce presumption the automatic rule in multi-count cases. Each case is, of course, also subject to the "reasonable likelihood" qualification. As discussed above, ${ }^{121}$ the Supreme Court uses two identifiable criteria to determine when a resentencing carries a "reasonable likelihood" of vindictiveness: first, the existence of a realistic opportunity to be vindictive, and second, the presence of a personal stake in the vindication of the original sentence. These two criteria suggest that vindictiveness can only exist in a case in which the same judge is forced to pass judgment more than once on the same conviction. ${ }^{122}$ Individual judges should have the opportunity to place a sentence on a unique count only once. ${ }^{123}$

However, this does not mean that judges should never be able to resentence on surviving counts of multi-count convictions. In some cases the dismissal of one count will cause a related second count to take on new significance. This will occur, for example, where a court initially convicts a defendant of two or more counts arising from the same conduct, only to have the conviction on one of the counts overturned on the grounds that the conduct only violated a single statute. The underlying nature of the remaining count has changed because, while in the first sentence the surviving count reflected only half of the substantive wrongdoing, on remand it comprehends all the misconduct. In such situations, dis-

221 See text accompanying notes 52-57.

${ }^{122}$ Colten, 407 US at 116-17, one of the early Pearce cases, specifically hints at such a result. In listing a series of circumstances that might lead a judge to resentence a defendant, the Court included the annoyance of being "asked to do over what it thought it had already done correctly." Id at 117.

${ }^{123}$ Nothing in this analysis should be read to suggest that Pearce might bar a judge from decreasing a sentence. The defendant's due process rights could not possibly be implicated by the imposition of a lesser sentence. 
cussed in further detail below, ${ }^{124}$ there is no valid reason to apply the Pearce presumption.

This Comment concludes that the Pearce presumption should apply to sentence increases on individual counts whenever the underlying nature of these counts has not been changed as a result of appeal. Where the underlying nature of the surviving counts has not changed, there is a "reasonable likelihood" that any increase is in direct response to (and a possible punishment for) exercising the right to appeal. By contrast, in situations where the underlying nature of the surviving counts has changed, there is no "reasonable likelihood" of vindictiveness because in a very real sense the defendant has never been sentenced on this specific count. ${ }^{125}$

3. Application of the "reasonable likelihood" standard to the specific multi-count case.

In most situations, the determination of whether or not the Pearce presumption should apply is straightforward. The test is whether a judge has been given the opportunity to hand down a sentence on an unchanged count which had already received a sentence.

a) Mischaracterized crimes and merger: situations which do not require the Pearce presumption. Several recurring situations do not require the Pearce presumption. For example; a defendant might be initially convicted of two counts of conspiracy. The appellate court might then determine that although the defendant did exactly what she was accused of doing, the acts alleged constitute, as a matter of law, only one act of conspiracy. ${ }^{126}$ Such a situation does not require the Pearce presumption. Forbidding the judge to increase the sentence attached to the single count in this type of case would mean the judge could only punish the defendant for the fraction of the crime originally covered by the surviving count. This type of case fits the proposed framework perfectly: the

124 See text accompanying note 126.

125 One could view this rule as an application of the first prong of the test. If the underlying nature of the count has changed as a result of the appeal, then it could be said that the sentence has not been increased. The results are identical regardless of whether one performs this analysis as part of the first or second prong of the Pearce test. See Section IV.D.1.

128 See Tice v State, 475 S2d 589, 590 (Ala Cr App 1984) (multiple drug convictions collapsed into one count on appeal); United States $v$ Colunga, 812 F2d 196, 197-98 (5th Cir 1987) (multiple conspiracy convictions collapsed into one count). 
judge should be allowed to resentence without worrying about the Pearce concerns when the underlying nature of the charge changes.

A second class of cases in which the Pearce presumption is not necessary to protect a defendant from potential vindictiveness involves the merger of two counts for purposes of sentencing. Such a situation might occur any time two individual counts, such as attempted murder and assault, merge for purposes of sentencing after the first trial but separate when the second trial results in a conviction only on the lesser charge. In such a situation, the judge might only have assigned a punishment to the more serious charge. ${ }^{127}$ If upon resentencing the judge cannot impose a new sentence on the remaining count, the defendant could enjoy an undeserved windfall. Since Pearce only proscribes sentences that exceed an earlier sentence, it does not apply to cases like this, because the defendant was never sentenced on the lesser charge.

b) Standard acquittals or dismissals of original convictions: situations in which the Pearce presumption is required. The Pearce presumption should apply when a second jury acquits or an appellate court dismisses a count based on substantive conduct that does not overlap with the other counts of the multi-count conviction. Because they are not based on the same substantive conduct as the dismissed count, the underlying nature of the remaining counts are unchanged. In such cases, the judge's "one chance" took place at the original sentencing. To allow the judge to increase the sentence attached to the remaining counts would invite judicial self-vindication and vindictiveness.

For example, suppose a court convicts a defendant of kidnapping and robbery at the first trial. At the second trial, the new jury votes for conviction on the kidnapping charge but finds reasonable doubt on the robbery charge and acquits. Unlike the merger example discussed above, here the substantive conduct underlying the dismissed count (robbery) is distinct from the substantive conduct which forms the basis of the conviction on the remaining count (kidnapping). ${ }^{128}$ To allow the judge to increase the sentence at-

127 See Fasenmyer v State, 457 S2d 1361, 1362-64 (Fla 1984).

128 As applied in this example, the underlying nature test appears somewhat similar to the "relevant conduct" provisions of the Federal Sentencing Guidelines. Guidelines Manual, $\S 1 B 1.3$ (cited in note 24). Yet, the relevant conduct provision covers a much broader class of situations than does the underlying nature test. While the Guidelines are concerned with any acts "that occurred during the commission of the offense of conviction, in preparation for that offense, or in the course of attempting to avoid detection or responsibility for that offense," Guidelines Manual, § $1 \mathrm{B1} .3(\mathrm{a})(1)$, the underlying nature test merely looks to whether the elements that make up the substantive conduct which forms the basis of an 
tached to the kidnapping charge to make up for the loss of the robbery conviction would encourage the judge to increase the kidnapping sentence in an attempt to justify the initial aggregate sentence. Such an action would nullify the effects of the defendant's successful appellate effort and should, therefore, be considered presumptively vindictive.

A variation on this fact pattern occurs when an appellate court determines an action which served as the basis for a conviction on one count does not, as a matter of law, constitute a statutorily recognized crime. For example, suppose a court convicts a defendant facing a multi-count indictment of selling drugs $\mathrm{X}$ and $\mathrm{Y}$, only to learn on appeal that at the time of the alleged sale, it was not illegal to sell drug $\mathrm{X}$. The conviction for selling drug $\mathrm{Y}$ stands. The substantive conduct which forms the basis of the conviction for selling drug $X$ has nothing to do with the other charge and the underlying nature of the conviction for selling drug $Y$ remains unchanged. Any increase in the sentence attached to the conviction for selling drug $\mathrm{Y}$ should invoke the Pearce presumption.

The above two examples involve a single criminal transaction. Sometimes a defendant will be tried on charges stemming from several distinct criminal acts. When an acquittal or dismissal occurs in such a situation, the argument for invoking the Pearce presumption becomes even stronger. For example, suppose a court initially convicts a defendant of three bank robberies but after an appeal the defendant wins acquittal on two of them. ${ }^{129}$ The underlying nature of the remaining conviction is unchanged. To allow enhancement of the sentence attached to the first count to make up for the dismissal of the second and third counts would again permit vindictiveness.

The proposed Pearce multi-count rule is more difficult to apply to a case in which one conviction mandates an automatic enhancement of the punishment attached to a second conviction. For example, suppose a judge issues a sentence which includes an enhancement mandated by the defendant's status, by virtue of a pre-

individual statutory conviction have changed. See also, Comment, Criminal Sentences that Reflect Actual Conduct: How Courts Apply the Relevant Conduct Provision of the Federal Sentencing Guidelines, 26 Gonzaga L Rev 537 (1990-91). The two tests are designed to serve vastly different goals. The Guidelines' relevant conduct provisions represent a policy decision to give sentencing authority to the trial judge in order to decrease the prosecutor's influence. See Freed, 101 Yale L J at 1713 (cited in note 106). By contrast, the underlying nature test is derived from the Supreme Court cases following Pearce, and it is concerned solely with meeting the mandates of the Due Process Clause of the Constitution.

128 See Bay, 820 F2d at 1512. 
vious conviction, as a habitual criminal. A court later overturns this earlier conviction (which was the source of the classification), mandating a reduction in the sentence imposed for the more recent set of crimes. ${ }^{130}$ On remand, the judge tries to adjust the sentence so that overall, despite the fact that the defendant is no longer legally a habitual criminal, there is no reduction in total prison time. Proper application of the proposed multi-count approach suggests application of the Pearce presumption in such a situation. The underlying nature of the remaining individual counts is unchanged. Because of the dismissal of other counts, the defendant is no longer a habitual criminal in the eyes of the law. The judge should not be able to adjust the sentence to treat her as one.

4. Both the "aggregate package" approach and the "modified aggregate package" approach lead to results inconsistent with the proposed "underlying nature" test.

The tests currently employed by the circuits are alternately over- and under-inclusive. The "aggregate package" rule allows several of the resentencings discussed above, such as the drug and robbery examples, to escape the Pearce presumption. ${ }^{131}$.This majority rule permits "self-vindication"132 by allowing a judge to reaffirm her initial sentence.

Similarly, the adoption of a simple count-by-count comparison test, or even the "modified aggregate package" rule, fails to take account of the fact that the appeals process may sometimes alter completely the significance of substantive conduct underlying individual counts. These relatively pro-defendant approaches would unnecessarily invoke the Pearce presumption in several situations in which it is unwarranted, perhaps resulting in inadequate punishment for some criminal activity. Neither the conspiracy nor merger examples given above warrant the Pearce presumption. ${ }^{133}$ The proposed underlying nature test avoids the lack of subtlety inherent in the bright-line approaches currently being used by the courts.

\footnotetext{
130 See Simonds v State, 799 P2d 1210, 1211-12 (Wy 1990).

131 See text accompanying notes 128-29.

132 Vontsteen, 910 F2d at 196 (Rubin dissenting), quoting Chaffin, 412 US at 27.

${ }^{133}$ See text accompanying notes $126-27$.
} 
C. Step Three: What Constitutes New "Identifiable Conduct" in the Multi-Count Situation?

The application of step three in multi-count cases is no different than application of step three in the classic Pearce case. A judge might justify an increase in an original sentence that suggests a reasonable likelihood of vindictiveness if the judge can point to new "identifiable conduct" on the record. ${ }^{134}$

Nevertheless, the Federal Sentencing Guidelines, despite their inapplicability to either of the first two steps of the Pearce test, do suggest one manner in which multi-count step three analysis might differ from classic step three analysis in federal cases. In certain situations the "relevant conduct" provision of the Guidelines"135 might offer a means for a judge wary of Pearce to maintain the severity of a multi-count defendant's aggregate sentence even after some of the original counts have been dismissed. ${ }^{136}$ Under the Guidelines, in determining the proper sentence, a judge may consider a range of conduct broader than that specifically covered by the count charged, ${ }^{132}$ including, in some instances, conduct for which the defendant was acquitted. ${ }^{138}$ To allow these acquittals to serve as new "identifiable conduct" sufficient to justify an increase in an original sentence would, however, expand the range of evidence available for use under step three beyond the categories already identified by the Supreme Court. ${ }^{139}$ In any event, the "relevant conduct" provision applies only in specific situations, thereby limiting the potential use of this provision to defeat the effect of Pearce in multi-count cases. ${ }^{140}$

${ }^{234}$ Pearce, 395 US at 726.

195 Guidelines Manual, § 1B1.3 (cited in note 24).

${ }^{136}$ Only one federal case has actually considered the "relevant conduct" provision in a Pearce case. See Dominguez, $951 \mathrm{~F} 2 \mathrm{~d}$ at 415 (holding, in what is arguably dicta, that under the facts of that case, the "real conduct" provisions of the Guidelines may justify a partial increase in the sentence attached to the remaining counts of a multi-count conviction.).

${ }^{137}$ See Guidelines Manual, $\$ 1 B 1.3$ (cited in note 24).

1so See United States v Isom, 886 F2d 736, 738-39 (4th Cir 1989).

130 See note 28.

${ }^{140}$ First, the scope of "relevant conduct," while broad, does have limits; courts may not consider all non-convicted improper acts. See Guidelines Manual, § 1B1.3 (cited in note 24). Second, a court may penalize a defendant only for non-convicted acts upon which there exists at least a "preponderance of the evidence" that the defendant committed the act. See, for example, United States v Cousineau, 929 F2d 64, 67 (2d Cir 1991); United States v Restrepo, 946 F2d 654, 655-56 (9th Cir 1991) (en banc) (collecting cases), cert den, 112 S Ct 1564 (1992). Some circuits actually require "clear and convincing evidence." See United States v Kikumura, 918 F2d 1084, 1103 (3d Cir 1990). Third, it is far from clear that courts can combine non-convicted acts with convicted acts to obtain a sentence equal in length to 


\section{Advantages of the Proposed Framework}

1. Adherence to the existing Pearce doctrine.

The proposed analysis, in which resolution of the multi-count issue hinges on the second step of the three-step analysis, represents only one of several manners in which the issue could be considered. Alternatively, for example, the analysis could focus on the first step. Under this approach, one might argue that a sentence could be said to have increased following appeal only when the underlying nature of the conviction attached to the sentence has not been changed. ${ }^{141}$ Similarly, the analysis could focus on step three. Any increase in the sentence attached to an individual count could be viewed to involve a "reasonable likelihood" of vindictiveness, thereby requiring judicial justification. Justification might be found in the substantive conduct that forms the basis of any dismissed counts. Under this approach, information about the conduct upon which dismissed charges were based could be reinterpreted by the second sentencer as new "identifiable conduct," and could thus justify a sentence increase on the remaining counts.

So long as the logic behind the the proposed underlying nature test for step two guides the analysis under a test designed for steps one or three, the results reached in the multi-sentencing cases would not necessarily change. Nevertheless, moving the analysis to either of these steps would pose significant problems. Moving the analysis to step one would shift the analysis away from the vindictiveness question - the central focus of Pearce. Furthermore, this shift would force decisions regarding the Pearce presumption in a context that lacks precedent to serve as a guide. Moving the analysis to step three, on the other hand, poses an even more substantial problem. Under existing case law, courts reach step three only after finding that a situation satisfies the first two elements of the three-step test. If all multi-count cases were decided on step three, regardless of their specific facts, there would be no reason not to consider all cases-multi- or single-count-under the third step. The three-step test would have collapsed to a fact-intensive onestep analysis.

While this Comment takes a particularly formalistic approach to Pearce and its three-step test, it is important to remember that

one justified had the court convicted the defendant on all charges. See United States $v$ Concepcion, 928 F2d 369, 389 (2d Cir 1992).

142 See note 125 and accompanying text. 
Pearce's central concern is vindictiveness. Only a step two analysis focuses on this crucial concern.

2. Promoting more thoughtful initial sentences.

In addition to meeting the requirements of Pearce, a system that offers judges only one opportunity to hand down a sentence on any individual count would encourage deliberation. Such a change will not necessarily limit a judge's discretion. It will only affect the time at which a judge may exercise this discretion. Judges will still be free to craft any statutorily permitted sentence they choose. They will simply have to consider all possible contingencies-including the chance of dismissal of some, but not all, of the individual counts-after the initial trial.

This, in turn, will provide defendants and the public with more information. Adoption of the underlying nature approach would enable defendants examining their convictions to make an accurate assessment of the benefits of pursuing an appeal, and it will give the public a more accurate picture of the type of sentences its laws are generating. Under the "aggregate package" approach this information is not readily available because the defendant knows that apparent success on appeal may or may not be negated by a judge on resentencing. ${ }^{142}$

Such a system will encourage some judges to find ways to make their sentences "appeal proof." Faced with a multi-count case, a judge who is determined to keep a defendant in jail for twenty years but is fearful that an appellate court might dismiss one or more counts could, subject to statutory limitations, sentence the defendant to a series of longer concurrent sentences rather than a series of shorter consecutive sentences. Thus, if a jury convicts the defendant of two counts, the judge could sentence her to two twenty year sentences to be served concurrently rather than sentence her to two ten year sentences to be served consecutively.

While such behavior is certainly possible, an argument based on this scenario proves too much. So long as sentencing is at all discretionary, judges will have the power to abuse their discretion. Crafting undeserved appeal-proof sentences in multi-count Pearce cases is simply one more area in which judges need to be trusted; even when properly applied, rules such as the Pearce presumption

\footnotetext{
142 While the information is clearly available under the "modified aggregate package" approach, that solution has the problem, discussed above, of being overinclusive. See text accompanying note 133 .
} 
can only curtail devious behavior to a certain degree. Furthermore, even if the modified count-by-count rule would encourage appealproof sentences, it is more just and more efficient that the defendant be aware of the futility of appeal earlier, through knowledge of the honest structure of the sentence, rather than later, through a post-appeal vindictive reshuffling of the punishment. ${ }^{143}$

\section{ConcLusion}

Courts must conduct resentencing in multi-count cases under a system that protects the defendant from the potential vindictiveness of the sentencing judge. In the more than two decades since Pearce, the Supreme Court has repeatedly modified and explained its presumption of vindictiveness test. Yet neither the "aggregate package" solution proposed by the majority of the circuits nor the "modified aggregate package" approach adopted by a minority of the circuits adequately analyzes the multi-count Pearce issue under the current three-step test. Proper application of that test mandates adoption of the proposed underlying nature approach. This more subtle solution will both protect defendants from the vindictiveness of a judge in search of self-vindication as well as promote careful and deliberate initial consideration of the appropriate punishment.

${ }^{243}$ See Bordenkircher v Hayes, 434 US 357, 368 \& n 2 (1978) (Blackmun dissenting) (using similar logic in the context of prosecutorial vindictiveness). 